theory, and the Court made no order in reference to it. I believe therefore that the decision is retroactive and that state courts will have to adjust themselves to that idea, as they did after the decision in Betts v. Brady.

The net results of this rather inconclusive discussion seem to me to be that in all criminal prosecutions for major offenses, if the state allows transcripts of the evidence to be prepared and used by defendants who pay for them the state, in order to be on the safe side, must furnish such transcripts to defendants unable to pay for them, except in cases where it is plain either that the appeal is frivolous or that defendants without transcripts are in as favorable a position as those with transcripts. The state must also pay in behalf of indigent defendants other expenses of appeal of the kinds that I have mentioned, unless provision is made for waiving the requirements. I do not think it can be said at the present time that the "implications" of the Griffin decision go beyond what I have just stated. If I am right the decision is not so revolutionary as some commentators seem to believe. ${ }^{23}$

\footnotetext{
${ }^{23}$ I have written the foregoing in the first person singular. I have done so partly to avoid circumlocutions and partly to make it plain that the views expressed and the errors pronounced are entirely my own.
}

\title{
GRIFFIN v. ILLINOIS: ANTECEDENTS AND AFTERMATH*
}

\section{Francis A. Allent}

When, in the spring of 1956, the United States Supreme Court handed down its decision in Griffin v. Illinois, ${ }^{1}$ most of those who follow the work of the Court immediately recognized that this was a case of more than passing interest and significance. The case is important, first of all, in its immediate holding. Its primary impact is felt in those states whose procedures, at the time of the decision, provided less than "adequate" opportunities for appeal to indigent defendants in criminal cases. But the decision may have a broader significance. In announcing the judgment of the Court, Mr. Justice Black says: "There can be no equal justice where the kind of trial a man gets depends on the amount of money he has. Destitute defendants must be afforded as adequate appellate review as defendants who have money enough to buy transcripts."' Such a principle, to say the least, contains the potentiality of growth. And its implications may extend to problems quite distinct from those involved in Griffin v. Illinois.

It is well, at the outset, to state as accurately as possible the holding in the case. The Court was divided 5-4. There is, strictly speaking, no Opinion of the

* An address delivered at the Ninth Annual Conference of Chief Justices, July 10, 1957, in New York.

$\dagger$ Professor of Law, University of Chicago.

1351 U.S. 12 (1956). $\quad 2$ Id., at 19. 
Court. Mr. Justice Black announced the Court's judgment in an opinion joined by three other justices. Mr. Justice Frankfurter filed a special concurrence. There are two dissenting opinions representing the views of the other four justices. It is true that, taking the opinions together, certain questions, some of them important, remain unanswered and await future clarification. But these difficulties ought not to be overstated. It seems clear that a majority of the Court has accepted at least the following proposition: When a State has adopted a system of criminal appeals, the Equal Protection Clause, and perhaps the Due Process Clause, of the Fourteenth Amendment, preclude the State from barring indigent defendants from appellate review simply because such defendants lack the means to submit a stenographic transcript or report of trial proceedings upon which appellate review is conditioned under state law. No doubt, the principle encompasses fees or other costs of appeal, as well. Just what means a State may employ to satisfy the requirements of "adequate" appellate review for indigent defendants is not wholly clear. But there is nothing obscure in the statement of the general proposition.

It is important, too, to understand what this case is not. Griffin v. Illinois is not one of that host of cases, which have so frequently engaged the courts' attention in recent years, involving the adequacy of state post-conviction procedures to adjudicate and remedy trial and pre-trial errors allegedly resulting in denial of defendant's constitutional rights. ${ }^{3}$ As Mr. Justice Black accurately observes in the Griffin case, if the alleged errors at the trial had involved constitutional rights, petitioners could have proceeded to a hearing under the Illinois Post-Conviction Hearing Act; ${ }^{4}$ and, if necessary, a stenographic transcript would have been supplied them despite their lack of means. But here, the alleged errors of which petitioners sought review in the state supreme court were of the non-constitutional sort, and hence the Post-Conviction Act was not applicable-such matters as errors in the admission or exclusion of evidence at the trial, the sufficiency of the evidence, and perhaps errors in instructions. The constitutional issues in the Griffin case thus do not involve the trial errors as such, but, rather, involve the appellate process itself. ${ }^{5}$ The constitutional right

${ }^{3}$ See, e.g., Brown v. Allen, 344 U.S. 443 (1953); Darr v. Burford, 339 U.S. 200 (1950); Wade v. Mayo, 334 U.S. 672 (1948); Marino v. Ragen, 332 U.S. 561 (1947); White v. Ragen, 324 U.S. 760 (1945).

${ }^{4}$ Ill. Rev. Stat. (1955) c. $28, \$ \S 826-830$.

${ }^{5}$ This is not to say, however, that the post-conviction procedures involving asserted denials of constitutional rights will wholly escape the impact of the Griffin principle. Thus, what of the case in which a petitioner in a coram nobis proceeding is denied a hearing by the state trial court on his allegations of denial of due process and, because of poverty, is precluded from perfecting appeal of this ruling in the state appellate court? Has there been an "exhaustion of state remedies" sufficient to permit a federal district court to order an habeas corpus hearing on petitioner's constitutional allegations?

These questions were only recently presented to the Court of Appeals for the Second Circuit in United States ex rel. Marcial v. Fay, 247 F.2d 662 (C.A. 2d, 1957), decided August 16, 1957. There the prisoner, attacking a 1935 conviction in a New York trial court, filed a petition 
asserted was the right to be free from the alleged discrimination on the part of the State in denying appellate review to petitioners which was supplied as matter of right to other members of the community possessing means to pursue the remedy.

From the date of its decision the Griffin case has provoked considerable discussion and comment. In much of the discussion the novelty of the holding has been emphasized. It cannot be denied that the Griffin decision contains elements of novelty; the precise problem of the case had not earlier received the attention of the Court. But it is important that the case be placed in its proper doctrinal context. So seen, it will be discovered, I think, that the case is part of a developing body of constitutional doctrine which has increasingly engaged the attention of the United States Supreme Court in recent years. The element of continuity with past developments, it seems to me, is more important to analysis and understanding of the case than the element of novelty. That the first section of the Fourteenth Amendment was to have important points of application to state systems of criminal procedure was clear almost from the beginning. Such great cases as Ex parte Virginia, ${ }^{6}$ decided in the years following close upon the end of the Civil War, illustrate the point. But it cannot be denied that in the modern period there has been a marked increase of tempo in the de-

for writ of error coram nobis in the trial court alleging that his conviction was invalid on due process grounds. The petition was denied without a hearing on the merits. Petitioner then filed notice of appeal to the Appellate Division and requested leave to proceed as a poor person. The motion was denied. Thereupon, he applied to the Court of Appeals of New York for permission to appeal in forma panperis, but his motion was again denied, presumably on the ground that the latter court has no jurisdiction to allow the appeal under the circumstances. It appears uncontroverted that petitioner was barred from review in the highest court of the state because of his inability to pay the expenses of an ordinary appeal. After the Supreme Court of the United States had denied certiorari, the prisoner filed a petition for habeas corpus in the federal District Court. Again the petition was denjed without a hearing for the reason, among others, that the petitioner had not "exhausted his state remedies." The federal Court of Appeals, in reversing the order of the District Court, held that there had been compliance with the exhaustion requirement despite older authority looking the other way. United States ex rel. Kalan v. Martin, 205 F.2d 514 (C.A. 2d, 1953); United States ex rel. Rheim v. Foster, 175 F.2d 772 (C.A. 2d 1949). This result is based in part on the Griffin case. Thus the court says: "To deny poor persons the right of federal habeas corpus on the ground that they did not utilize state procedures beyond their means would clearly conflict with at least the spirit of these decisions." United States ex rel. Marcial v. Fay, supra, at 665. This portion of the court's rationale may be regarded as dubious if it is meant to be suggested that state appellate procedures are not "adequate" in the constitutional sense simply because they permit a "sifting out" of frivolous forma pauperis appeals in the lower courts on a finding that the appeal is not being conducted in good faith. Such a power, of course, resides in the lower federal courts and it seems unlikely that the Supreme Court in Griffin intended to cast doubt on the validity of the federal statute. See 62 Stat. 1954 (1948), as amended, 28 U.S.C.A. $\$ 1915$ (1950). The Court of Appeals in the Marcial case, however, points out that in the federal system, presumably unlike the situation which obtained in New York, the refusal of the lower court to certify that the appeal in forma panperis is taken in good faith may itself be attacked in the appellate court as unwarranted. Cf. Johnson v. United States, 353 U.S. 565 (1957). Another aspect of the problem is canvassed in Application of Sears, 152 F.Supp. 55 (S.D. Cal., 1957).

6100 U.S. 339 (1879). 
velopment of Fourteenth Amendment law relating to criminal procedure. Recent years have seen the Court speaking to a host of issues, including the use of coerced confessions, evidence obtained by illegal search and seizure and other illegitimate methods, the rights of counsel, the use of perjured testimony known by the prosecution to be such, and many more. ${ }^{7}$ It is customary to consider these developments very recent ones. But the modern period of development of Fourteenth Amendment law dates back at least a quarter of a century to the case of Powell v. Alabama, ${ }^{8}$ decided in 1932, or even perhaps to the case of Moore v. Dempsey, ${ }^{9}$ decided in 1923 . This is by no means the first instance in our constitutional history in which a period of a generation and more has produced important and extensive developments of constitutional doctrine. It is worth noting, too, that the modern development of Fourteenth Amendment law as it relates to criminal procedure is not the work of a small group of likeminded judges. Since the decision in Powell $\%$. Alabama, twenty-five justices appointed by eight Presidents of the United States have occupied positions on the Court. No doubt, a wide range of attitude and viewpoint has been represented. Despite this diversity, however, the expansion of doctrine in the field has moved steadily forward.

One of the factors of the Griffin case which has probably contributed to the impression of novelty is the very fact that it is the state appellate process which was held to offend the constitutional standards. In relation to the whole history of Anglo-American legal development, the criminal appeal can be regarded almost a modern innovation. It is sometimes forgotten that the system of criminal appeals as we know it today is very largely a product of the nineteenth century. Thus, although developments originated in the states somewhat earlier, it was not until 1879 in the federal system that writs of error were authorized to be issued by the Circuit Courts in criminal cases-and even then on a discretionary basis. ${ }^{10}$ It was not until the Criminal Appeal Act, $1907,{ }^{11}$ that appellate review of criminal convictions in England was placed on a modern and satisfactory basis. Since the criminal appeal is a comparatively recent device, the problems of applying constitutional standards to the criminal appellate process are somewhat different from those involving the criminal trial. For unlike the criminal trial, there is no similar body of common-law precedent and practice to guide the framing and application of constitutional standards to the criminal appeal. Moreover, the impression, though largely an erroneous one, has been some-

\footnotetext{
${ }^{7}$ An extensive literature has developed. See, e.g., Boskey and Pickering, Federal Restrictions on State Criminal Procedure, 13 U. of Chi. L. Rev. 266 (1946); Scott, Federal Restrictions on Evidence in State Criminal Cases, 34 Minn. L. Rev. 489 (1950); Allen, The Wolf Case: Search and Seizure, Federalism, and the Civil Liberties, 45 IIl. L. Rev. 1 (1950); Hall, Police and Law in a Democratic Society, 28 Ind. L. J. 133, 154 (1953); Paulsen, The Fourteenth Amendment and the Third Degree, 6 Stan. L. Rev. 411 (1954).
}

8287 U.S. 45 (1932).

9261 U.S. 86 (1923).
10 20 Stat. 354, c. 176 (1879).

117 Edw. VII, c. 23 (1907). 
times held that the state appellate processes are substantially immune from federal constitutional regulation. No doubt, the source of this impression is in certain language of the United States Supreme Court itself. Thus, in McKane v. Durslon" the Court made its often-repeated statement: "A review by an appellate court of the final judgment in a criminal case, however grave the offense of which the accused is convicted, was not at common law and is not now a necessary element of due process of law."13 But this is not the end of the matter and certain qualifications have been clearly recognized since 1894 when $M c K a n e$ v. Durston was decided. Nor is this surprising. For, although the criminal appeal is of comparatively recent origin, it has rapidly become an important and integral part of the legal process of all American jurisdictions. One measure of its importance is the frequency of reversals in criminal cases. Thus between 1949 and 1954 nearly thirty percent of Illinois criminal appeals resulted in reversals of convictions. Similarly high percentages of reversal have occurred in some of the other states. ${ }^{14}$ As long ago as 1915, Mr. Justice Pitney speaking for the Supreme Court in Frank v. Mangum ${ }^{15}$ said: ". . . while the Fourteenth Amendment does not require that a State shall provide for an appellate review in criminal cases . . , it is perfectly obvious that where such an appeal is provided for, and the prisoner has had the benefit of it, the proceedings in the appellate tribunal are to be regarded as a part of the process of law under which he is held in custody by the State. . ." Although it is true that the proposition so announced was relied on by the Court in Frank v. Mangum to affirm a state conviction, a similar proposition has been stated by the Court when convictions were reversed. Thus, in Cole v. Arkansas ${ }^{17}$ a state judgment was reversed after the supreme court of the state had affirmed a conviction under a section of a statute different from that which had been charged in the information and under which the case had been submitted to the jury.

But the earlier cases of greatest relevance are those like Cochrane v. Kansas ${ }^{18}$ and Dowd v. Cook ${ }^{19}$ in which prisoners, incarcerated in state penitentiaries, were prevented from pursuing appeals of their convictions by prison rules prohibiting prisoners from filing petitions in court. ${ }^{20}$ In these cases, the United States

12153 U.S. 684 (1894).

${ }^{13}$ Id., at 687.

14 The figures from Illinois are derived from the Biennial Reports of the Attorney-General of Illinois for the years 1950, 1952, and 1954. See Brief for Petitioners, Griffin v. Illinois (No. 95, October Term, 1955, Supreme Court of the United States) 21 et seq. See also Vernier and Selig, The Reversal of Criminal Cases in the Supreme Court of California, 2 So. Calif. L. Rev. 21 (1928); After Reversal-What? 27 J. Crim. L. and Crim. 929 (1937); Reversals in Illinois Criminal Cases, 42 Harv. L. Rev. 566 (1929).

15237 U.S. 309 (1915).

${ }^{16}$ Id., at 327.

18316 U.S. 255 (1942).

${ }^{17} 333$ U.S. 196 (1948).

19340 U.S. 206 (1951).

${ }^{20} \mathrm{~A}$ similar rule obtained for a period of time in the Illinois prison system. See White $v$. Ragen, 324 U.S. 760, 762 n. 1 (1945); United States ex rel. Bongiorno v. Ragen, 54 F.Supp. 973 (N.D. Ill., 1944). 
Supreme Court found that the rules denying prisoners access to the courts deprived them of the equal protection of the laws. It may be said, of course, that it is one thing when a defendant is directly denied access to the courts by state action in the form of a prison rule and quite another when a defendant is unable to appeal simply because he cannot afford costs which the state demands of all appellants. But the distinction is perhaps deprived of much of its force when other considerations are borne in mind. Thus, the prison rules in Cochrane and Dowd forbade only the prisoner from maintaining his appeal. Presumably, the prisoners in these cases, if they had been able to afford it, could have pursued their appeals through attorneys. That they did not do so probably indicates their financial inability to do so. Thus, in the earlier cases as well as in Griffin, poverty was a significant element in the finding that equal protection had been withheld.

But it is not my purpose to suggest that the result in the Griffin case was inevitable or that a contrary result was foreclosed by earlier decisions of the Court. The 5-4 vote in the case is probably all that is necessary to demonstrate the contrary. But the more one considers the Griffin case in context, the more he becomes persuaded that the result is squarely in the main current of an important development of constitutional development which has been steadily unfolding for a generation and more. Understanding of the case and its implications is advanced, it seems to me, by the recognition that in the Griffin case we are not dealing with a biological sport or mutation.

Speculating on the projections of the Griffin decision into other areas of legal procedure provides what is certainly a fascinating but a hazardous occupation. In his Holmes Lecture delivered at the Harvard Law School in 1956,21 $\mathrm{Mr}$. Justice Schaefer of the Illinois Supreme Court has suggested that the rationale of the Griffin case casts serious doubt on the continued vitality of the constitutional rule in the right-to-counsel cases which, under some circumstances, relieves the states of the obligation to supply counsel to indigent defendants in serious non-capital cases. ${ }^{22}$ One may doubt that the Court by its decision in the Griffin case intended to undermine the authority of the line of decisions based on Belts v. Brady. ${ }^{23}$ Moreover, it is not difficult to suggest certain distinctions, some of them of a rather formalistic sort, which may distinguish the problem of the counsel cases from that in Griffin v. Illinois. Nevertheless, Justice Schaefer's point contains much cogency. If, as in Bells v. Brady, one ap-

21 Schaefer, Federalism and State Criminal Procedure, 70 Harv. L. Rev. 1 (1956).

22 "The analogy to the right to counsel case is close indeed: if a state allows one who can afford to retain a lawyer to be represented by counsel, and so to obtain a different kind of trial, it must furnish the same opportunity to those who are unable to hire a lawyer. Since indigence is constitutionally an irrelevance, it would seem that a successful argument might be based upon the proposition that the defendant by reason of his poverty is deprived of a right available to those who can afford to exercise it." Id., at 10.

${ }^{23} 316$ U.S. 455 (1942). See also Bute v. Illinois, 333 U.S. 640 (1948); Foster v. Illinois, 332 U.S. 134 (1947); Tomkins v. Missouri, 323 U.S. 485 (1945). 
proaches the problem of right to counsel as a problem of due process of law, he may be able to conclude that, despite the disadvantages attendant upon the absence of legal representation in a serious felony case, the defendant's injury in at least some circumstances does not depart so far from an abstract conception of "fair hearing" to raise the situation to the constitutional level. But if as in Griffin, the constitutional test is that of equal protection of the laws-if, that is, we ask whether defendant is getting the same brand of justice as the man with means to employ skillful counsel-the denial of legal representation, sanctioned by Betts v. Brady, may be more difficult to maintain. One other area of speculation might be mentioned. In a federal case, United States ex rel. Smith v. Baldi, ${ }^{24}$ a defendant urged that he had been deprived of a fair trial by the failure of the state to supply him, without cost, the assistance of expert psychiatrists whose services he could not hire and which were necessary to prepare and maintain his defense of insanity. Only recently the late Judge Jerome Frank, in his book Not Guilty, reminds us that in some legal systems of the world such a contention would not be regarded as startling. In the Scandinavian countries, he tells us, "Not only is every accused in a criminal case entitled to counsel of his own choosing at government expense, to make all necessary investigations (including searches for witnesses and documents) and to supply analyses of handwriting as well as expert testimony on behalf of the defendant." ${ }^{25}$ And, indeed, legislative developments of a similar, though more limited character, have begun to appear in some of the American states. Of course, nothing in the Griffin case suggests that such assistance may be demanded by the impoverished defendant as a matter of constitutional right, nor is there any present basis for believing that such an extension of principle will be made. In speculation of this sort, the caveat uttered by Mr. Justice Frankfurter with reference to another problem may well be heeded: ". . . hypothetical situations can be conjured up, shading imperceptibly from the circumstances of this case and by gradations producing practical differences despite seemingly logical extensions." ${ }^{26}$

Perhaps it would be more profitable to turn from the attempt to forecast the effects of the Griffin case on the future law and to consider some of the concrete and immediate problems the case poses. No better way occurs to me than to consider the efforts in Illinois to comply with the mandate of the Griffin case.

It should be noted, first of all, that the issue of providing indigent defendants with transcripts for appeal was by no means a new question in Illinois. The proposal had been actively considered and debated for a decade-and-a-half before the ruling in Griffin. Four years before Griffin one of the local law reviews asserted: "At least thirty other states provide some form of appeal in forma pauperis; surely the time has come for Illinois to join their ranks."

\footnotetext{
24192 F.2d 540 (C.A. 3d, 1951).

${ }^{26}$ Rochin v. California, 342 U.S. 165, 174 (1952).

${ }^{25}$ Frank and Frank, Not Guilty 87 (1957).

${ }^{27}$ Post-Trial Remedies: The Illinois Merry-Go-Round Breaks Down, 46 Ill. L. Rev. 900 , 914 (1952).
} 
Though reform by legislation was not achieved, this assertion represented the views of many informed persons in the state.

In Illinois, direct review of criminal convictions is accomplished by writ of error. Unless a bill of exceptions is included in a properly certified record, review in the appellate courts is restricted to the so-called common law or mandatory record. The mandatory record consists of such items as the indictment, record of arraignment, plea, verdict and judgment. The Supreme Court of Illinois has frequently, and without exception, held that when review is taken on the mandatory record, only errors appearing on the face of these documents may be considered..$^{28}$ Thus, one seeking review of a criminal conviction on the mandatory record is foreclosed from raising such issues as sufficiency of evidence, errors in rulings on evidence, prejudicial behavior on the part of court or counsel, and the like: in short, most of the issues which provide the grist of ordinary appellate review. Such issues may be included in the record by filing a bill of exceptions or report of proceedings with the trial judge within 100 days after entry of judgment or "within any extension thereof granted within the 100 days or extension thereof." 29 But the filing of the bill of exceptions ordinarily requires submission of a stenographic transcript of trial proceedings. And in the pre-Griffin period, transcripts for appeal were provided indigent defendants only in capital cases. It is true that under Illinois law the requirement of a bill of exceptions might theoretically be satisfied by submission of a narrative bill or a bystander's bill of exceptions. But the difficulties in settling a bystander's bill confronting a convicted prisoner in custody are so formidable that it provides no practical alternative-a fact clearly conceded by counsel for Illinois in the argument of the Griffin case. ${ }^{30}$

The problems created by this situation became critical in the 1940's when the courts became innundated with petitions by prisoners alleging that their convictions involved denial of constitutional rights. In Illinois the problem developed something in this fashion: Illinois prisoners, having no feasible method of asserting their constitutional claims by direct review of their convictions, channeled these issues into collateral procedures such as habeas corpus or coram nobis. These collateral remedies proved incapable of bearing the burden thrust upon them. Here, then, was probably the primary reason for the fact that during the mid-forties more petitions for relief were filed in the United States Supreme Court by Illinois prisoners than were filed by the combined prison populations of the other forty-seven states and the federal penal system. ${ }^{31}$ Illinois responded to the crisis by passage of the Post-Conviction Hearing Act ${ }^{32}$

${ }^{28}$ Typical are the statements appearing in People v. O'Connell, 411 IIl. 591, 104 X.E.2d 825 (1952).

${ }^{29}$ Illinois Supreme Court Rules $65 . \quad 30351$ U.S. 12, 16 (1956).

31 Information supplied by the Clerk of the Supreme Court of the United States.

${ }^{32}$ Ill. Rev. Stat. (1955) c. $28, \$ \$ 826-830$, as amended. 
which, particularly as interpreted after the case of Jennings v. Illinois, ${ }^{33}$ created what might be regarded as a substitute review process for indigent prisoners insofar as errors involving constitutional rights are concerned. But still the problem of review of non-constitutional issues remained. One of the unfortunate consequences of the Illinois Post-Conviction Act--legislation which has proved both wise and necessary - was that by solving the critical problems of review of constitutional issues, the passage of the Act reduced the impetus for fundamental reform of the writ of error procedure in criminal cases.

The Illinois Supreme Court responded to the decision in Griffin v. Illinois by the adoption of a rule of court which achieves important changes in Illinois writof-error procedure. Rule 65-1 was made effective, as amended, on September 26,1956 . The Rule affects the rights of two groups of indigent defendants: those convicted after the decision in the Griffin case and those convicted before. The problems differ in the two categories. As to those convicted subsequent to Griffin, the Rule authorizes the convicted person to file a petition with the trial judge requesting that he be furnished a stenographic transcript of the trial proceedings. The petition must be verified by the petitioner and state facts establishing his poverty. If the judge finds defendant to be without financial means, he shall order the reporter to transcribe his notes and deliver a copy of the transcript to the defendant without cost. Thereafter, defendant pursues his appeal as any other appellant. He must, that is, submit a bill of exceptions to the judge within 100 days of judgment or in any authorized period of extension. According to information supplied by the State Attorney's Office, since the adoption of the Rule, some seventy-one of these petitions had been granted by the courts of Cook County as of June 20, 1957.

In drafting this portion of the Rule, the Illinois Supreme Court was required to resolve a number of important and difficult issues. It will be recalled that the opinion of Mr. Justice Black in the Griffin case suggests that in at least some situations the constitutional requirement of "adequate" appellate review may be met by devices other than supplying indigent defendants with stenographic transcripts, such as, for example, the bystander's bill. It was the decision of the Illinois court, however, to make stenographic transcripts available in these cases. Experience with bystander's bills suggests that it is a difficult remedy even for an experienced attorney to pursue. Certainly the difficulties are immeasurably increased for an inexperienced layman deprived of mobility and freedom by a criminal conviction.

Another decision of almost equal importance in framing the Illinois Rule was to authorize the granting of a transcript in these cases without requiring any finding on the part of the trial judge as to the substantial character of the issues which defendant proposes to raise on appeal. Here the Rule departs from the practice under the federal statute and that of several of the states. The decision, no doubt, was based on the conviction that such a sifting process at the ${ }^{33} 342$ U.S. 104 (1951). 
trial court level has not worked well where it has been attempted. In part this may be due to the fact that, without the transcript before him, the trial judge may have difficulty evaluating the substantial character of defendant's contentions. But more important, if the transcript is denied by the trial judge, it becomes a particularly difficult task for the appellate court to determine, without the transcript before it, whether the trial judge was guilty of an abuse of discretion. As the late Judge Jerome Frank asks in his dissenting opinion in United States v. Johnson, "But how can the existence of such a meritorious appeal be shown unless the defendant has access to a transcript of the events at the trial?" 35 The Illinois Rule thus deals with the problem of frivolous appeals at the appellate level rather than at the trial level.

But it is with reference to the second group of defendants-those convicted before the Griffin decision-that the most difficult questions are posed. There is, first of all, some doubt as to whether the Griffin case requires that provision be made for them at all. Even if the four members of the Court adhering to Mr. Justice Black's opinion intended that result, the other five justices seem to have taken a different view. The four justices who dissented took the position that there is no constitutional obligation to supply transcripts in any case. And Mr. Justice Frankfurter clearly maintains that the rule of the case may be given only a prospective effect. ${ }^{36}$

The Illinois Supreme Court, however, decided that since a constitutional right is involved, a remedy should be supplied all those in custody whose access to the appellate courts had been foreclosed through poverty. Accordingly, all those convicted before Griffin were given until March 1, 1957, to file a petition in the trial court requesting a stenographic transcript of their trial. Upon finding that the defendant lacked financial means at the time of his conviction and was presently indigent, the trial judge was directed to order the transcription of so much of the trial proceedings as is necessary for the prisoner to present his contentions to the appellate court. If satisfied with the accuracy of the transcript, the judge was authorized to certify the record irrespective of the time limitations which ordinarily apply. Review in the appellate court is not a matter of right. Instead, the prisoner files a "petition for a Writ of Error Under Rule 65-1." If the petition is granted by the appellate court, review will proceed as in any other writ of error proceedings.

That the Rule in its retroactive aspects presents real problems cannot be denied. The magnitude of the administrative burden is suggested by the fact that before the cut-off date of March 1, 548 petitions for transcripts were granted by courts in Cook County alone. Thirty-five petitions were denied for being out of time. ${ }^{37}$ To date, the Supreme Court of Illinois has not acted on any of the petitions for writ of error. Obviously, these petitions will prove a substantial burden to the court in the months immediately ahead. There has been a prob-

${ }^{34} 238$ F.2d 565 (C.A. 2d, 1956). $\quad{ }^{35}$ Id., at $569 . \quad 3631$ U.S. 12, 25-26 (1956).

${ }^{37}$ Information supplied through the courtesy of the State's Attorney of Cook County. 
lem of costs. It was necessary to request a substantial appropriation from the state legislature to support the program..$^{38}$ And the usual problems have arisen. Reporters have died and transcription of their notes has proved difficult or impossible. In one of these cases, five hundred pounds of notes taken by a deceased reporter have been submitted to six other reporters, none of whom has been able to transcribe them. These problems, of course, arise under any system. But naturally, when the transcripts demanded involve trials held many years before, these difficulties arise much more frequently. Finally, complaints have been heard that the trial judges have shown undue liberality in ordering the entire record of proceedings transcribed, despite the fact that the Rule provided only that portions relevant to petitioners' contentions be transcribed.

These difficulties, and others which might be mentioned, ${ }^{39}$ have appeared. There is no point in denying that some of them are serious. But certainly, it is not too soon to conclude that they are not insuperable. Surely, there is no reason to believe that Illinois will be unable to deal with these problems as satisfactorily as they have been dealt with in the federal system and in twothirds of the states. There is reason, too, to hope and expect that ultimately the result of this effort will be a higher quality of criminal justice in Illinois.

${ }^{35}$ H.B. 1346, 1954 session of the Illinois General Assembly, appropriating a sum of $\$ 250,000$, passed the legislature and was approved by the Governor.

${ }^{39}$ One of the weaknesses in Rule 65-1 may be the failure to specify the right of petitioner to have counsel appointed in his behalf to assist in the preparation of the petition for a transcript and in fulfilling the other requirements of the Rule. Compare the recently adopted Act 239 of the Territory of Hawaii, approved by the Governor of the Territory of Hawaii, June $3,1957$.

\section{THE EFFECT OF GRIFFIV v. ILLINOIS ON THE STATES' ADMINISTRATION OF THE CRIMINAL LAW}

The United States Supreme Court's decision in Griffin v. Illinois ${ }^{1}$ established a new Fourteenth Amendment constraint upon state court criminal administration, and makes advisable a re-evaluation of time-honored practices and statutes regarding the state's obligation to the indigent prisoner who seeks an appeal from his conviction. In its narrowest scope the decision holds that a state which requires a transcript of record for appellate review of criminal convictions must furnish the same to an indigent prisoner who pursues a timely appeal from his conviction. ${ }^{2}$ But the Court's rationale portends a greater significance for the decision than the mere furnishing of transcripts for appeal:

1351 U.S. 12 (1956). The decision provoked a rash of comments in law reviews. See Fairman, The Supreme Court 1955 Term, 70 Harv. L. Rev. 83, 121-29 (1956); Criminal Procedure -Due Process and Equal Protection Held To Require Free Transcripts for Indigent Convicts, 1956 Ill. L. Forum 501; Constitutional Law-Post-Conviction Due Process-Right of Indigent to Review of Non-Constitutional Trial Errors, 55 Mich. L. Rev. 413 (1957); Constitutional Law: Due Process and Equal Protection-Right of an Indigent Defendant to a Transcript of the Trial, 4 U.C.L.A. L. Rev. 274 (1957).

2 It is unclear from the Court's opinion whether its holding was premised on the Due Process or Equal Protection Clauses or both. See discussions in Mich. L. Rev., op. cit. supra note 1, at 416-18; Harv. L. Rev., op. cit. supra note 1, at 126-29. 